\title{
Work To Family Facilitation as a Predictor of Job Satisfaction, Affective Commitment and Job Performance in Academia
}

\author{
Farhan Sarwar $^{1 *}$, Tahir Masood Qureshi², Siti Aisyah Panatik ${ }^{3}$ \\ ${ }^{1}$ Faculty of Economics and Business Administration, University of Education, Lahore, Pakistan \\ ${ }^{2}$ College of Business Administration, American University in the Emirates, Dubai, UAE \\ ${ }^{3}$ School of Human Resource Development, Faculty of Social Sciences and Humanities, Universti Teknologi Malaysia, Johor, Malaysia
}

* Corresponding author: sarwarfarhan@gmail.com

\begin{abstract}
Work to Family Facilitation considers that time and other resources spent on the job by an individual can have a positive impact on family life. The current study tests to what extent this perception affects the employee's level of job satisfaction, affective commitment, and self-rated job performance. A systematic random sample of 293 faculty members from 30 public and private universities of Pakistan filled an online survey. Results from path analysis performed in AMOS indicate that Work to Family Facilitation is significant and positive predictors of all three outcomes variables. Moreover, both job satisfaction and affective commitment mediate path leading from work to family facilitation and self-rated job performance such that job satisfaction precedes affective commitment in the causal chain. Hence by devising family-friendly HR policies, effective job designs and fostering environment that is family supportive will result in enhanced employee performance. Similarly hiring employees with resourceful psychological traits or interventions to enhance resourceful psychological states can result in a greater perception of work to family facilitation. Discussion and implications are followed by future research directions.
\end{abstract}

Keywords: Work-Family Facilitation, Job Satisfaction, Organizational Commitment, Job Performance

(C) Readers Insight Publication

\section{INTRODUCTION}

Work-family linkages represent ways in which demands and resources in one domain influence the roles across the domain (Sarwar, Panatik, \& ur-Rehman, 2019). For long conflict has dominated the research literature in work-family linkages. Individuals feel that they have to divide their time and energy resource to meet the demands of both domains and this division may be skewed towards one domain since resources are scarce (Greenhaus \& Powell, 2003). However there is a growing recognition of the notion that work and family life can positively influence one another such that participation of an individual in work can ease or facilitate participation in home life due to gain of experiences, skills and opportunities and vice versa, termed as "work-family facilitation"(or facilitation: Frone, 2003). Empirical research reveals that bidirectional facilitation significantly correlated with various work and non-work outcomes including job satisfaction, organizational commitment, performance, physical and psychological health, parentchild interaction, family satisfaction, marital satisfaction and personal well-being (Aryee, Srinivas, \& Tan, 2005; Karatepe \& Bekteshi, 2008; Karatepe \& Magaji, 2008; Sarwar, Waqas, \& Imran, 2014; Steenbergen, Ellemers, \& Mooijaart, 2007; Volman, Bakker, \& Xanthopoulou, 2013). Although research has probed into the relationship of facilitation with work attitudes (Sarwar et al., 2014), limited research has explored its influence on job performance of academic faculty.

\section{WORK-FAMILY FACILITATION: THEORETICAL FOUNDATION}

Integrating three previously established theories of positive organizational scholarship(Cameron, Dutton, \& Quinn, 2003), ecological system theory (Bronfenbrenner, 1986) and conservation of resource theory (Hobfoll, 1989), and considering work and family domains as a microsystem, Wayne, Grzywacz, Carlson, and Kacmar (2007) developed the most comprehensive theory for work-family facilitation up to date termed as resource gain development (RGD) theory. RGD postulates that range of personal characteristics and environmental resources acts as resources and coupled with a natural tendency towards positivity, development, and growth leads to the experience of facilitation from one microsystem to others. Four types of gains that are possible due to resource from environment and personal characteristics are developmental gains (acquiring new skills and perspectives), affective gains (positive emotions), capital gains (financial, social asset or health) and efficiency gains (enhanced efficiency in both microsystems). Work-family facilitation splits into two bi-directional constructs, work to family facilitation and family to work facilitation. Work to family facilitation (W-FF) is defined as the extent to which participation of an individual in roles within work-life facilitates or ease the roles played in family life. For instance a manager who works for a long time and suffers job strain may experience conflicting situation in terms of time and energy in family domain. However, justified compensation would facilitate for more resources at home which can be enjoyed by employees and their families. Similarly, involvement in multiple roles may provide learning opportunities which may ease life at home for tasks such as 
decision making, problem-solving and handling, resolving conflict, dealing with relatives, etc (Steenbergen \& Ellemers, 2009). Although both facilitation and conflict co-exist, family-supportive work environment and policies would enhance an individual employees perception of facilitation (Sarwar et al., 2014).

Existing literature reveals that employee's perception of work to family facilitation has a positive impact on job satisfaction, affective commitment and job performance (Steenbergen et al., 2007). Hill (2005) found that work to family facilitation has a positive relationship with job and life satisfaction and negative relationship with stress. Similarly perception of work to family facilitation was found to be significantly and positively related to enhanced physical and psychological well-being (Frone, 2003) spouse relationship, parent-child interaction, occupational commitment, job satisfaction, higher productivity(Butler, Grzywacz, Bass, \& Linney, 2005), job performance and negatively related to level of absenteeism(Steenbergen, 2007).

We expect that in the relationship between W-FF and faculty's job performance, job satisfaction and organizational commitment would explain the mediating process. Both job satisfaction and organizational commitment have been studied (separately) as mediators in number of previous studies with job performance as outcome variable in only few studies. In a study conducted in UAE, Yousef (2000) found that organizational commitment mediates the relationship of transformational leadership with job satisfaction and job performance. Employees who were more committed exhibited greater satisfaction and better performance on the job. Similarly job satisfaction was found to be a significant mediator in path leading from workplace stressors to affective commitment(Yousef, 2002).

\section{ACADEMICS IN PAKISTAN}

After promulgation of higher education commission in 2003 as a new regulatory authority of higher education to enhance the quality and outreach of higher education in Pakistan, the scenario of university academics has tremendously changed in last decade and a half. The traditional relaxed nature of university faculty jobs is replaced with bundles of curricular and co-curricular activities. Faculty members are expected to carry out research-oriented activities and participate in job fairs, counsel students, perform administrative duties, create liaison with industry and keep abreast with latest knowledge of their respective fields. They are expected to acquire Mphil or Ph.D., as their promotions are tied to attainment of these research degrees. Unfortunately they have low financial and workplaces resources and are expected to perform at high standards in teaching and research which are main cause of occupational stress amongst university faculty in Pakistan (Khan, Yusoffa, \& Azam, 2014). Previous researches related to job satisfaction, organizational commitment and job performance of faculty members have focused upon nature of job, working conditions, salary, career growth and perceived organizational justice as predictors of job satisfaction and organizational commitment of faculty(Cano \& Castillo, 2004; E. Malik \& Naeem, 2011; M. E. Malik, Nawab, Naeem, \& Danish, 2010). Although in previous literature we find studies regarding work-family conflict of academic faculty in Pakistan (Rehman \& Waheed, 2012; Sana \& Aslam, 2018), yet there is a dearth of literature with respect to academic faculty's W-FF. To study the job performance and work attitudes of faculty members is important due to their profound effect on future human resource of a country which may hamper psychologically or skill-wise due to lack of performance or negative job attitudes (Naeem, Mirza, Ayyub, \& Lodhi, 2019).

\section{STUDY HYPOTHESIS}

This is the first study to propose both job satisfaction and organizational commitment can be mediators between W-FF and selfrated job performance of academics in Pakistan. Following hypothesis are proposed
H1: perception of work to family facilitation amongst university faculty has a positive predictor of a) self-rated job performance b) job satisfaction c) affective commitment

H2: in the relationship between perception of work to family facilitation and self-rated job performance, a) job satisfaction and/or b) affective commitment are mediators.

Following diagram reflects the hypothesized model

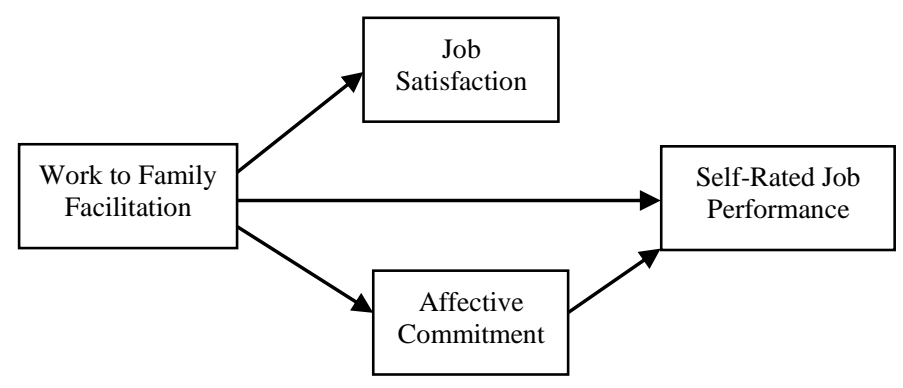

\section{METHOD}

A non-contrived, correlational and survey-based study was conducted. We collected sample from faculty of 30 universities in Pakistan. The criteria for inclusion of universities was presence of faculty member's emails addresses on their websites. Assumption of homogeneity amongst university sample was assumed due to HEC being single regulatory authority. It was also ensured that universities are selected from all four provinces of Pakistan and both public and private sectors so that there is a representative sample. Criteria for inclusion for final sample were full time teaching faculty members. List of email addresses of faculty members was copied from respective websites and pasted in excel sheet in a column which totaled 3219. An online survey form was created using google docs and its link was emailed to 800 randomly selected emails addresses. The reason to adopt this procedure was lack of a list which could serve as a sampling frame. By the cut-off date, 326 forms returned by the cutoff date of which 293 completed forms were utilized for data analysis. The demographic frequency distribution of final sample is depicted in table 1 . The sample was homogenous with respect to sector with $51.5 \%$ from public and $48.5 \%$ from private sector.

Table 1. Frequency distribution of the sample

\begin{tabular}{lcc}
\hline & Number & Percent\% \\
\hline Gender & & \\
Male & 208 & 71.0 \\
$\quad$ Female & 85 & 29.0 \\
Age in Years & & \\
$\quad$ Less than 29 & 86 & 29.4 \\
Between 30 to 39 & 111 & 37.9 \\
$\quad$ Between 40 to 49 & 49 & 16.7 \\
$\quad$ Above 50 & 47 & 16.0 \\
Education in years & & \\
14 years/equivalent & 1 & 0.3 \\
16 years/ equivalent & 44 & 15.0 \\
18 years/equivalent & 148 & 50.5 \\
PhD or equivalent & 100 & 34.1 \\
Designation & & \\
$\quad$ Research Associate & 21 & 7.2 \\
Lecturer & 115 & 39.2 \\
Assistant Professor & 96 & 32.8 \\
Associate Professor & 30 & 10.2 \\
Full Professor & 31 & 10.6 \\
Sector & & \\
$\quad$ Public & 151 & 51.5 \\
Private & 142 & 48.5 \\
\hline Total & $\mathbf{2 9 3}$ & $\mathbf{1 0 0 . 0}$ \\
\hline
\end{tabular}

\section{INSTRUMENTS}




\section{W-FF}

We utilized a 12 item scale developed by (Steenbergen, 2007) in her doctoral dissertation to measure W-FF of faculty. The scale measures facilitation on four dimensions of time-based W-F facilitation, energy-based W-F facilitation, behavioral-based W-F facilitation, and psychological W-F facilitation. Every dimension is assigned three items each. Sample item (energy-based W-F facilitation) is "when I get home from work I often feel energized, making me more like participating in activities /responsibilities at home" $(\alpha=0.805)$. Responses are recorded on five-item Likert Scale i.e. strongly disagree (1) to strongly agree (5).

\section{Job satisfaction}

We used five items job satisfaction index (Brayfield \& Rothe, 1951) to measure the level of job satisfaction in an individual faculty member. It has five items that measures on a five-point Likert scale strongly disagree(1) to strongly agree (5). A sample item is: "I feel fairly well satisfied with my present work". $(\alpha=0.885)$. This particular scale has been extensively used and proven to be reliable in existing studies (Ilies, Wilson, \& Wagner, 2009; Judge, Heller, \& Klinger, 2008; Judge, Locke, Durham, \& Kluger, 1998).

\section{Affective Commitment}

We measured affective organizational commitment on a scale developed by Mowday, Steers, and Porter (1979). Out of the total ten items, four were dropped to improve the reliability of the scale $(\alpha=$ 0.860). A sample item is: "I find that my values and the organization's values are very similar". Responses are recorded on the five-item Likert Scale i.e. strongly disagree (1) to strongly agree (5).

\section{Self-Rated Job Performance}

Due to the ease of data collection, self-rated job performance has been used as a reliable tool of job performance in previous literature. We measured job performance using an assortment of scales. Chirumbolo and Areni (2010) assembled an 11 item self-rated job performance scale adopting six items from Abramis (1994), two from Chirumbolo and Areni (2005) and introduced the remaining three items themselves. In the first nine items faculty members were asked to rate their performance using very badly (1) to very well (5). Sample job features were "make decisions", "achieve objectives", "finish things on time" etc. two additional items were relevant to overall job performance. The first item was "I achieved all my job goals in last six months" to be rated on 5 points Likert scale of strongly disagree(1) to strongly agree (5) and second item was "In the last six month, your performance was...." To be rated on 5 points very poor (1) to very good (5). The scale had $\alpha$ value of 0.837 which coincide with reliability of .84 found by Chirumbolo and Areni (2010)

\section{ANALYSIS}

We computed composites of the study constructs in SPSS using summation approach (compute variable). The composites were used for further analysis. First we conducted descriptive statistics analysis in SPSS. Secondly path analysis using AMOS(Arbuckle, 2009) was employed to construct the schematic diagram of study and test the significance of individual relationships as hypothesized. In order to test the mediation of job satisfaction and affective commitment in the path leading from work to family facilitation to job performance, Baron \& Kenny (1986) causal step method of mediation was used. Several path analyses were carried out by reshuffling the link to attain the best model and to check how variation of paths affects relationship and significance of different linkages.

RESULTS

Table 2 depicts the results of descriptive statistics and interconstructs correlations. The results of mean depict a positively skewed data which means the sample is positioned at higher side of all the study variables. Standard deviation for all the variable is less than one depicting low scatter of data around mean. Correlation indicate that all the study variables have positive and significant correlations. Work to family facilitation was positively and significantly correlated with job satisfaction, affective commitment and job performance. Similarly, job satisfaction and affective commitment were positively related to job performance and with one another.

\begin{tabular}{lrrccc}
\hline & Mean & S.D & $\mathbf{1}$ & $\mathbf{2}$ & $\mathbf{3}$ \\
\hline 1.W-FF & 3.20 & .84 & & & \\
2.JS & 3.83 & .94 & $.405^{* *}$ & 1 & \\
3.AC & 3.94 & .74 & $.235^{* *}$ & $.570^{* *}$ & 1 \\
4.JP & 4.15 & .48 & $.200^{* *}$ & $.349^{* *}$ & $.499^{* *}$ \\
\hline
\end{tabular}

**. Correlation is significant at the 0.01 level (2-tailed).

$\mathrm{W}-\mathrm{FF}=$ Work to Family Facilitation, JS $=$ Job Satisfaction,

$\mathrm{AC}=$ Affective Commitment, $\quad \mathrm{JP}=$ Job Performance

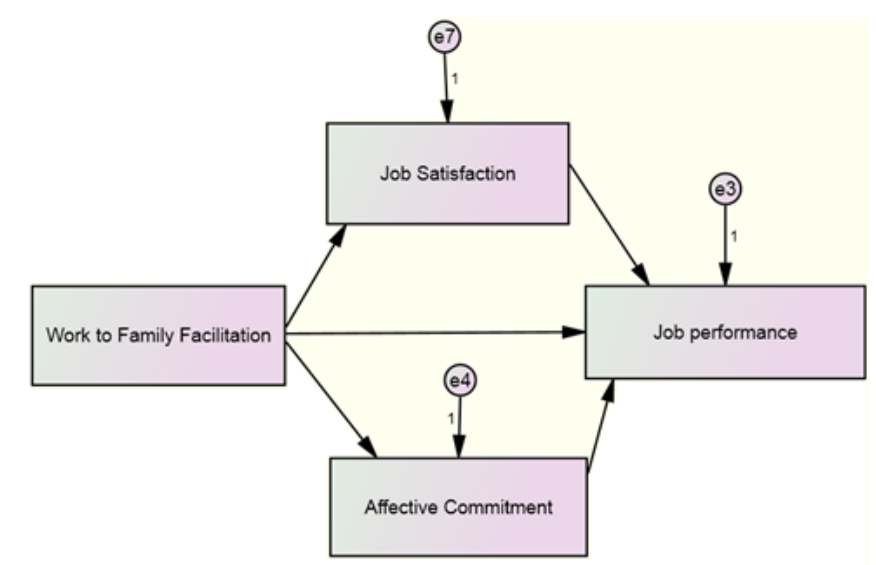

Figure 1: Proposed path model in AMOS

We tested several variations of the path model to find the best fit model. First, all paths as depicted in figure 2 were included to check the significance of linkage between each endogenous (job performance, affective commitment and job satisfaction) and exogenous (work to family facilitation) variable. However, in this case the proposed model was not an adequate fit (model 1). Secondly, two just identified models were tested, firstly be linking organizational commitment to job satisfaction (model 2) and secondly by reversing the link that is from job satisfaction to organizational commitment(model 3). In a just identified model ever variable is connected to another variable with degree of freedom equals to zero. Normally just identified model is used to test the significance of several relationships and attain a best fit adequate model. Finally the insignificant paths from model2 (since it had least number of insignificant relationships) were removed to get an adequate fit model (model 4).

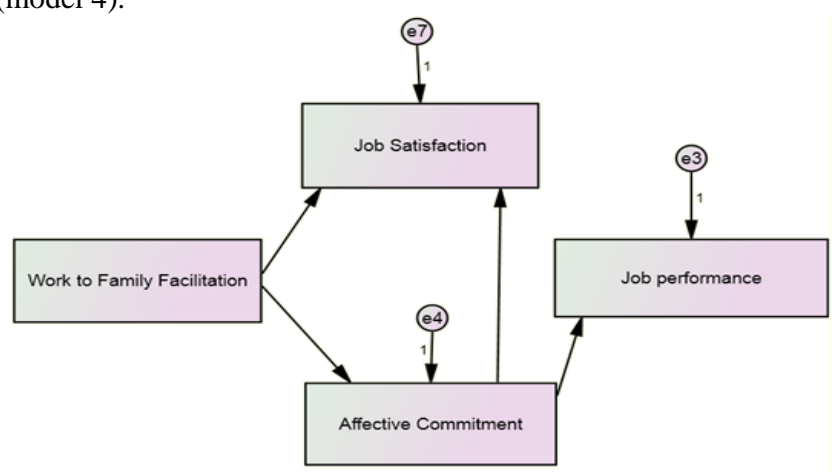

Figure 2: Adequate fit model no 4

For model 4 GFI, CFI and RMSEA were 0.993, 0.994 and 0.57 respective depicting a good fit to data (Hu \& Bentler, 1999). In order 
to check if the reason for the insignificant path from work to family facilitation and job performance is because both job satisfaction and organizational commitment full explained the process, we removed the paths from job satisfaction and affective commitment to job performance as depicted in figure 4 (model 5). Path coefficients from all four models are depicted in table 3.

Table 2: Results for study model

\begin{tabular}{|c|c|c|c|c|c|c|c|}
\hline $\begin{array}{l}\text { Path } \\
\text { from }\end{array}$ & $\begin{array}{l}\text { Path } \\
\text { to }\end{array}$ & $\begin{array}{l}\text { Model } \\
1 \\
\text { (Fig.2) }\end{array}$ & $\begin{array}{l}\text { Model } \\
2\end{array}$ & $\begin{array}{l}\text { Model } \\
3\end{array}$ & $\begin{array}{l}\text { Model } \\
4 \\
\text { (Fig. 3) }\end{array}$ & Model 5 & $\begin{array}{l}\text { Model } \\
6 \\
\text { (Fig. 5) }\end{array}$ \\
\hline W-FF & JS & $.452^{*}$ & $.320^{*}$ & $.452^{\star}$ & $320^{*}$ & $.452^{*}$ & $.452^{*}$ \\
\hline W-FF & $A C$ & $.209^{*}$ & $.209^{*}$ & .005 & $.209^{*}$ & $.209^{\star}$ & ---- \\
\hline W-FF & $\mathrm{JP}$ & .039 & .039 & .039 & ---- & $.115^{*}$ & ---- \\
\hline JS & JP & .035 & .035 & .035 & ---- & ---- & ---- \\
\hline$A C$ & $\mathrm{JP}$ & $.289^{*}$ & $.289^{*}$ & $.289^{*}$ & $.325^{*}$ & ---- & $.325^{\star}$ \\
\hline AC & JS & ---- & $.632^{*}$ & ---- & --- & ---- & ---- \\
\hline JS & $A C$ & ---- & ---- & $.451^{*}$ & ---- & ---- & $.452^{*}$ \\
\hline & .875 & 1.000 & & .993 & .769 & .993 \\
\hline \multicolumn{2}{|l|}{$\mathrm{CFI}$} & .678 & 1.000 & & .992 & .313 & .996 \\
\hline \multicolumn{2}{|c|}{ RMSEA } & .542 & .377 & & .057 & .441 & .032 \\
\hline \multicolumn{2}{|c|}{ Chi Square } & $\begin{array}{l}98(p= \\
0)\end{array}$ & --- & & $\begin{array}{l}3.894(p \\
=.143)\end{array}$ & $\begin{array}{l}173.7(p= \\
0)\end{array}$ & $\begin{array}{l}3.906 \\
(p \\
.272)\end{array}=$ \\
\hline
\end{tabular}

${ }^{*} \mathrm{P}<0.05$

From the results depicted in table 3, hypothesis H1a, H1b, and $\mathrm{H} 1 \mathrm{c}$ were accepted because job performance, job satisfaction, and affective commitment were significantly predicted by work to family facilitation in absence of job satisfaction and affective commitment's linkage with job performance. Yet the hypothesis H1a was partially accepted as the relationship in our proposed model was insignificant. So we can say that in the presence of job satisfaction and affective commitment, work to family facilitation is an insignificant predictor of job performance. This also depicts that either of the two work attitudes or both acts as full mediators (Baron \& Kenny, 1986). An interesting finding which was not in the scope of the current study revealed that both job satisfaction and affective commitment are highly significant predictor of each other and both can precede other in the causal chain of occurrences which is consistent with existing literature and is still a probing question to the researchers(Currivan, 2000).

We conducted a mediation analysis using causal steps approaches (Baron \& Kenny, 1986). From the result of mediation analysis, it is evident that independently both job satisfaction and affective commitment is full mediator in path leading from work to family facilitation and job performance such that inclusion of any one of these job attitudes changes the significance of the path. Yet inclusion of both as mediating variable makes job satisfaction insignificant. Additionally job satisfaction acts as a mediator in path from work to family facilitation and affective commitment. This makes us believe a possible existence of double mediating variable in action such that path from work to family facilitation links to job satisfaction which leads to organizational commitment which leads to job performance. As far as mediation is concerned $\mathrm{H} 2 \mathrm{a}$ and $\mathrm{H} 2 \mathrm{~b}$ are accepted but not in the way we had anticipated. Model 6 (figure 5) was designed in AMOS as a final proposed model and resulted in a more adequate model as compared to model 4 as depicted in table 3 .

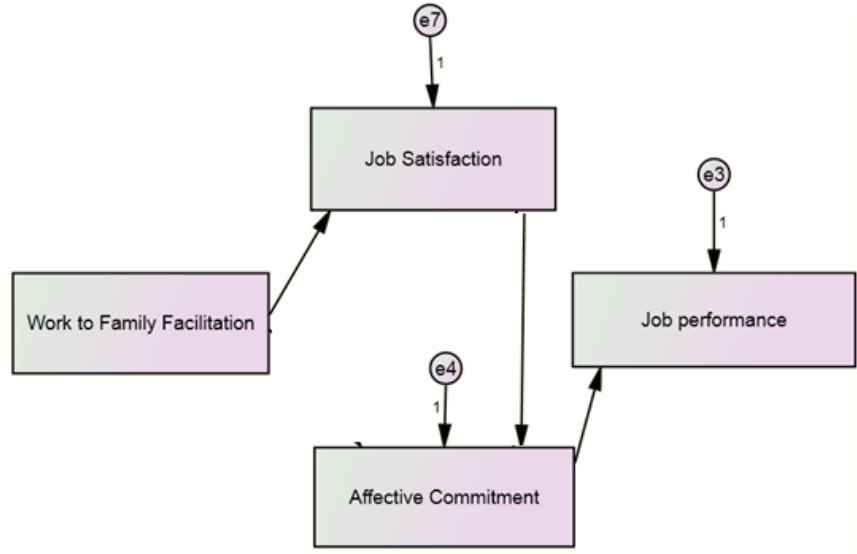

Figure 3: Final serial mediation model

\section{DISCUSSION}

First, we endeavored to find whether faculty's perception of work to family facilitation predicted job satisfaction, affective commitment, and job performance. In all three cases the results were as per hypothesized and in accordance with existing literature (Aryee et al., 2005; Hill, 2005; Srivastava, Srivastava, \& Srivastava, 2009; Steenbergen, 2007). The positive impact of work to family facilitation upon work attitude owes to positive resources that in the first place increased the perception of facilitation and then gave rise to the positive work attitudes of job satisfaction and organizational commitment. Secondly, it was found that there are two mediators in the link between work to family facilitation and job performance. Conclusively according to our finalized model, work to family facilitation gives rise to job satisfaction. Job satisfaction, in turn, acts as predictor for organizational commitment which yet predicts job performance. These links have been tested multiple times in previous literature this study outlined their natural order of occurrence and affecting one another. To the best of our knowledge this is the first attempt to relate work to family facilitation with job performance by testing for job satisfaction and organizational commitment as the mediating variables.

The approach towards adopting the positive perspective of the work-family linkage means expecting beneficial outcomes for the employee and employer, in terms of enhanced positive job attitudes of satisfaction and commitment in work domain with employees perception of better job performance. Through this research we can acknowledge the importance of work-life balance in life of university faculty. If they perceive that due to their academic jobs, their family life is getting easier and has improved in quality, their response will be with an attitude of higher job satisfaction and greater commitment towards their organization. Family life is important for an individual (Voydanoff, 2014), and when they perceive that their workplace is supportive towards family and found ease to balance both, the appraisal towards one's current job and organizational becomes positive (Morganson, Litano, \& O'Neill, 2014). Moreover these two attitudes of job satisfaction and organizational commitment would have positive influence on job performance of the academics(Callaghan \& Coldwell, 2014; Yousef, 2000). lead to a perception of greater performance, as they rated themselves. In their research study, Steenbergen and Ellemers (2009) found that family life supportive home environment, increase employees perception of facilitation, reduce conflict and enhanced feeling of job satisfaction. Organizations, recognizing the positive impact of W-FF upon various workplace attitudes and behaviors have started devising policies that allow them to ease their participation in family life (Grzywacz \& Marks, 2000). According to Steenbergen, Ellemers, Haslam, and Urlings (2008), positive appraisals and informational support also enhance perception of work-family facilitation. Similarly, Wayne, Musisca, and Fleeson (2004) also reported a positive relationship 
between positive personality traits in big five and work-family facilitation.

\section{CONCLUSION}

Human resource professionals must device such policies which enhance an individual feeling of work to family facilitation. In case of academics, it is advised that their job design consideration should be based upon balancing their work-life with family life. The findings have implications for university administration which could benefit not only faculty members but their students as well. Positive attitudes and better performance would ultimately benefit future human capital and improve research activities. One cannot expect better results from faculty members by controlling them as industrial workers. Time bindings, less autonomy over class timings or curriculum, unnecessary burden of administrative tasks or overloaded with researchbased or other activities could ultimately result in low level of work to family facilitation.

Generalizability of research due to a sample of faculty members and self-reported survey especially self-rated job performance are two limitations of the current research. Self-reported surveys are affected by self-serving bias although we expected highly educated and intellectual faculty members to be more logical in surveys. It is recommended that future research be based upon a larger sample from diverse industries and instead of self-reported job performance, the supervisor reported job performance or more objective measure of job performance be employed for more authentic results. Moreover other job attitudes and behavioral outcomes like OCB, absenteeism, turnover intentions, stress, and subjective wellbeing can be incorporated in the current model as outcomes of work-family facilitation to get a more holistic picture of its beneficial effects.

\section{REFERENCES}

Abramis, D. J. (1994). Work role ambiguity, job satisfaction, and job performance: Meta-analyses and review. Psychological reports, 75(3f), 1411-1433.

Arbuckle, J. (2009). Amos 18 user's guide: SPSS Incorporated.

Aryee, S., Srinivas, E. S., \& Tan, H. H. (2005). Rhythms of Life: Antecedents and Outcomes of Work-Family Balance in Employed Parents. Journal of Applied Psychology, 90(1), 132-146. doi:https://doi.org/10.1037/0021-9010.90.1.132

Baron, R. M., \& Kenny, D. A. (1986). The moderator-mediator variable distinction in social psychological research: Conceptual, strategic, and statistical considerations. Journal of personality and social psychology, 51(6), 1173-1182. doi:https://doi.org/10.1037//0022-3514.51.6.1173

Brayfield, A. H., \& Rothe, H. F. (1951). An index of job satisfaction. Journal of Applied Psychology, 35(5), 307.

Bronfenbrenner, U. (1986). Ecology of the family as a context for human development: Research perspectives. Developmental psychology, 22(6), 723.

Butler, A., Grzywacz, J. G., Bass, B., \& Linney, K. (2005). Extending the demands control model: A daily diary study of job characteristics, work family conflict and work family facilitation. Journal of Occupational and Organizational Psychology, 78(2), 155-169. doi:https://doi.org/10.1348/096317905x40097

Callaghan, C. W., \& Coldwell, D. (2014). Job Satisfaction and Job Performance: The Case of Research Productivity. Journal of Economics, 5(1), 97-113. doi:10.1080/09765239.2014.11884988

Cameron, K. S., Dutton, J. E., \& Quinn, R. E. (2003). Positive organizational scholarship: Foundations of a new discipline: Berrett-Koehler Publishers.

Cano, J., \& Castillo, J. (2004). Factors explaining job satisfaction among faculty. Journal of Agricultural Education, 45(3), 65-74.

Chirumbolo, A., \& Areni, A. (2005). The influence of job insecurity on job performance and absenteeism: The moderating effect of work attitudes. SA Journal of Industrial Psychology, 31(4).

Chirumbolo, A., \& Areni, A. (2010). Job insecurity influence on job performance and mental health: Testing the moderating effect of the need for closure. Economic and Industrial Democracy, 31(2), 195-214.

Currivan, D. B. (2000). The causal order of job satisfaction and organizationa commitment in models of employee turnover. Human Resource Management Review, 9(4), 495-524.
Frone, M. R. (2003). Work-family balance. Washington, DC: American Psychological Association.

Greenhaus, J. H., \& Powell, G. N. (2003). When work and family collide: Deciding between competing role demands. Organizational Behavior and Human Decision Processes, 90(2), 291-303.

Grzywacz, J. G., \& Marks, N. F. (2000). Reconceptualizing the work-family interface: An ecological perspective on the correlates of positive and negative spillover between work and family. Journal of Occupational Health Psychology, 5(1), 111.

Hill, E. J. (2005). Work-family facilitation and conflict, working fathers and mothers, work-family stressors and support. Journal of Family Issues, 26(6), 793. doi:https://doi.org/10.1177/0192513x05277542

Hobfoll, S. E. (1989). Conservation of resources: A new attempt at conceptualizing stress. American psychologist, 44(3), 513-524. doi:https://doi.org/10.1037//0003-066x.44.3.513

Hu, L., \& Bentler, P. M. (1999). Cutoff criteria for fit indexes in covariance structure analysis: Conventional criteria versus new alternatives. Structural Equation Modeling: A Multidisciplinary Journal, 6(1), 1-55. doi:https://doi.org/10.1080/10705519909540118

Ilies, R., Wilson, K. S., \& Wagner, D. T. (2009). The spillover of daily job satisfaction onto employees' family lives: The facilitating role of workfamily integration. Academy of Management Journal, 52(1), 87-102.

Judge, T. A., Heller, D., \& Klinger, R. (2008). The dispositional sources of job satisfaction: A comparative test. Applied Psychology, 57(3), 361-372.

Judge, T. A., Locke, E. A., Durham, C. C., \& Kluger, A. N. (1998). Dispositional effects on job and life satisfaction: The role of core evaluations. Journal of Applied Psychology, 83(1), 17.

Karatepe, O. M., \& Bekteshi, L. (2008). Antecedents and outcomes of workfamily facilitation and family-work facilitation among frontline hotel employees. International Journal of Hospitality Management, 27(4), 517-528. doi:https://doi.org/10.1016/j.ijhm.2007.09.004

Karatepe, O. M., \& Magaji, A. B. (2008). Work-Family Conflict and Facilitation in the Hotel Industry. Cornell Hospitality Quarterly, 49(4), 395-412. doi:https://doi.org/10.1177/1938965508326282

Khan, A., Yusoffa, R. B. M., \& Azam, K. (2014). Factors of Job Stress among university teachers in Pakistan A conceptual review. Journal of Management Info, 2(1). doi:https://doi.org/10.31580/jmi.v2i1.6

Malik, E., \& Naeem, B. (2011). Impact of perceived organizational justice on organizational commitment of faculty: Empirical evidence from Pakistan. Interdiscip J Res Bus, 1, 92-98.

Malik, M. E., Nawab, S., Naeem, B., \& Danish, R. Q. (2010). Job satisfaction and organizational commitment of university teachers in public sector of Pakistan. International Journal of Business and Management, 5(6) P17.

Morganson, V. J., Litano, M. L., \& O’Neill, S. K. (2014). Promoting WorkFamily Balance Through Positive Psychology: A Practical Review of the Literature. The Psychologist-Manager Journal, 17(4), 221-244. doi:https://doi.org/10.1037/mgr0000023

Mowday, R. T., Steers, R. M., \& Porter, L. W. (1979). The measurement of organizational commitment* 1. Journal of Vocational Behavior, 14(2), 224-247.

Naeem, A., Mirza, N. H., Ayyub, R. M., \& Lodhi, R. N. (2019). HRM practices and faculty's knowledge sharing behavior: mediation of affective commitment and affect-based trust. Studies in Higher Education 44(3), 499-512. doi:https://doi.org/10.1080/03075079.2017.1378635

Rehman, R. R., \& Waheed, A. (2012). Work-family conflict and organizational commitment: Study of faculty members in Pakistan universities. Pakistan Journal of Social and Clinical Psychology, 9(2), 23-26.

Sana, F., \& Aslam, N. (2018). Effect of Role Ambiguity and Role Conflict in Predicting Work-Family Conflict Among Teachers. Pakistan Journal of Psychological Research, 33(2), 349-365.

Sarwar, F., Panatik, S. A., \& ur-Rehman, Z. (2019). How Work-Family Conflict, Enrichment and their Interaction Influence Work-Family Balance Satisfaction among University Faculty? International Journal of Recent Technology and Engineering, 8(2s), 48-56.

Sarwar, F., Waqas, M., \& Imran, A. (2014). Work Family Facilitation as Predictor of Job Satisfaction and Organizational Commitment: A Study of University Faculty in Pakistan. World Applied Sciences Journal 32(1), 146-152.

Srivastava, S., Srivastava, U. R., \& Srivastava, A. (2009). Qualitative exploration into the phenomenon of work-family facilitation in Indian context. Indian Journal Social Science Researches, 6(1), 92-102.

Steenbergen, V. E. F. (2007). Work-family facilitation: a positive psychological perspective on role combination. Department Psychology/Social and Organizational Psychology, Faculty of Social and Behavioural Sciences, Leiden University, 
Steenbergen, V. E. F., \& Ellemers, N. (2009). How Family-Supportive Work Environments and Work-Supportive Home Environments Can Reduce Work-Family Conflict and Enhance Facilitation. In R. Crane \& J. Hill (Eds.), Handbook of families and work: interdisciplinary perspectives (pp. 79): United press of America.

Steenbergen, V. E. F., Ellemers, N., Haslam, S. A., \& Urlings, F. (2008) There is nothing either good or bad but thinking makes it so: Informational support and cognitive appraisal of the work-family interface. Journal of Occupational and Organizational Psychology, 81(3), 349-367.

Steenbergen, V. E. F., Ellemers, N., \& Mooijaart, A. (2007). How work and family can facilitate each other: Distinct types of work-family facilitation and outcomes for women and men. Journal of Occupational Health Psychology, 12(3), 279.

Volman, F. E., Bakker, A. B., \& Xanthopoulou, D. (2013). Recovery at home and performance at work: A diary study on self-family facilitation. European Journal of Work and Organizational Psychology, 22(2), 218234

Voydanoff, P. (2014). Work, family, and community: Exploring interconnections: Psychology Press.

Wayne, J. H., Grzywacz, J. G., Carlson, D. S., \& Kacmar, K. (2007). Workfamily facilitation: A theoretical explanation and model of primary antecedents and consequences. Human Resource Management Review, 17(1), 63-76. doi:https://doi.org/10.1016/j.hrmr.2007.01.002

Wayne, J. H., Musisca, N., \& Fleeson, W. (2004). Considering the role of personality in the work-family experience: Relationships of the big five to work-family conflict and facilitation. Journal of Vocational Behavior, 64(1), 108-130. doi:https://doi.org/10.1016/s00018791(03)00035-6

Yousef, D. A. (2000). Organizational commitment: a mediator of the relationships of leadership behavior with job satisfaction and performance in a non-western country. Journal of Managerial Psychology, 15(1), 6-24.

Yousef, D. A. (2002). Job satisfaction as a mediator of the relationship between role stressors and organizational commitment: A study from an Arabic cultural perspective. Journal of Managerial Psychology, 17(4), 250-266. 